\title{
Adiposis Dolorosa
}

National Cancer Institute

\section{Source}

National Cancer Institute. Adiposis Dolorosa. NCI Thesaurus. Code C84540.

A rare genetic disorder characterized by the development of painful lipomas during adulthood, especially in menopausal women. Associated symptoms include fatigue, obesity, confusion and depression. 